DOI: $10.15255 /$ KUI.2016.036

\title{
Primjena polimera u farmaceutskoj industriji
}

\section{1. Šoljić Jerbić*}

Pliva Hrvatska d. o. o., Istraživanje i razvoj, Prilaz baruna Filipovića 25, 10000 Zagreb

\begin{abstract}
\| Sažetak
Polimeri i polimerni materijali već su dugi niz godina prisutni u farmaceutskoj industriji, gdje se primjenjuju kao pomoćne tvari za oblikovanje konvencionalnih lijekova ili za izradu ambalaže za lijekove. Međutim sve je veća primjena polimera u naprednim terapijskim sustavima, gdje je oslobađanje djelatne tvari kroz dulje razdoblje kontrolirano najvećim dijelom brzinom degradacije polimera. Poželjno je da polimeri koji se unose u tijelo čovjeka budu biorazgradljivi, a to znači da s vremenom potpuno degradiraju na netoksične produkte koji se mogu prirodnim putem izlučiti iz organizma. Također, moraju biti i biokompatibilni, pri čemu u dodiru s organizmom ne izazivaju neželjene nuspojave iako se u tkivu mogu zadržati dulje vrijeme. Tako dizajnirani kompleksni terapijski sustavi u kojima su polimeri funkcionalne djelatne tvari imaju brojne prednosti kao što je jednostavnost i lokaliziranost primjene, produljeno i kontrolirano vrijeme djelovanja lijeka, što znatno smanjuje učestalost primjene. Na taj način smanjena je mogućnost javljanja neželjenih nuspojava, s ciljem poboljšanja kvalitete života pacijenata. Postoje različito dizajnirani sustavi za dostavu lijeka, a njihov pregled te mehanizam djelovanja bit će opisani u sklopu ovog rada zajedno s istaknutom ulogom polimera za svaki pojedini sustav.
\end{abstract}

$\|$ Ključne riječi

Polimeri, farmaceutski oblici, kontrolirano oslobađanje, hidrogelovi

\section{Uvod}

Farmaceutski proizvodi mogu se podijeliti prema načinu oslobađanja djelatne tvari na farmaceutske oblike s trenutnim oslobađanjem i farmaceutske oblike s kontroliranim/ produljenim oslobađanjem djelatne tvari. Tradicionalni pristup liječenja bolesti podrazumijeva uzimanje klasičnih farmaceutskih oblika oralnim putem kao što su tablete i kapsule na dnevnoj razini. Kod takvih sustava lijek se oslobađa u probavnom sustav u vrlo kratkom i definiranom vremenu te brzo apsorbira i dospijeva u sistemsku cirkulaciju pacijenta. ${ }^{1,2}$ Koncentracija djelatne tvari u plazmi kroz određeno vrijeme iz klasičnog farmaceutskog oralnog oblika s trenutnim oslobađanjem nakon dvostruke primjene prikazan je na slici 1. Na slici se mogu primijetiti tri područja. Prvo područje odnosi se na podterapijsku razinu lijeka u krvi pacijenta koja nije dovoljna za bilo kakav terapijski učinak. Zatim slijedi terapijsko područje, gdje je razina lijeka optimalna i zadnje područje u kojem koncentracija lijeka prelazi najvišu sigurnu razinu lijeka u plazmi. ${ }^{3}$ lako se klasični farmaceutski oblici s trenutnim oslobađanjem mogu upotrebljavati prilikom liječenja akutnih i kroničnih bolesti, postoji nekoliko ograničenja kao što je potreba za čestim i višestrukim doziranjem te mogućnost razvoja nuspojava s obzirom na to da koncentracija lijeka može prelaziti najvišu sigurnu razinu u krvi. Navedeni nedostatci mogu se prevladati primjenom farmaceutskih oblika s kontroliranim/produljenim oslobađanjem, odnosno farmaceutskih pripravaka gdje je oslobađanje lijeka i njegova apsorpcija te dospijeće u sistemsku cirkulaciju regulirana samim farmaceutskim oblikom.

*Dr. sc. Ivana Šoljić Jerbić

e-pošta: ivana.soljicjerbic@pliva.com

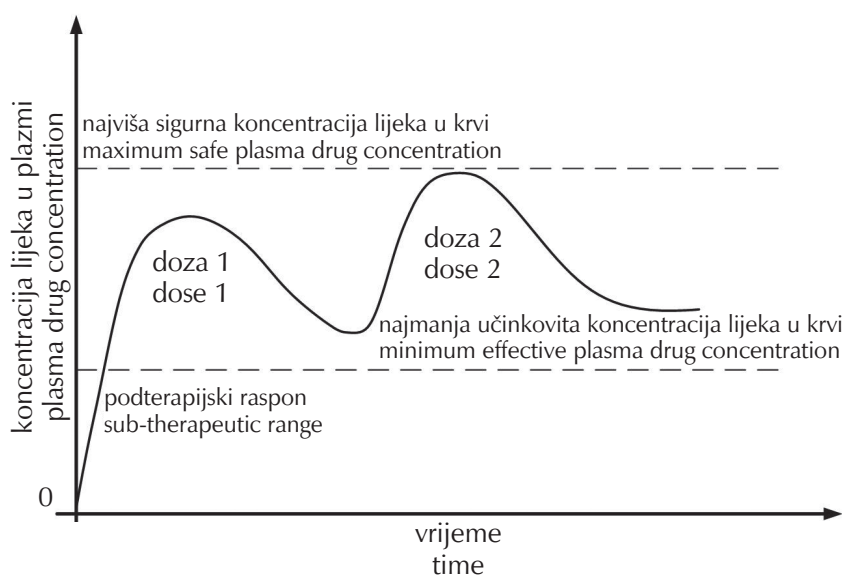

Slika 1 - Koncentracija lijeka u plazmi kao funkcija vremena nakon oralne primjene dvije doze iz farmaceutskog oblika s trenutnim oslobađanjem kao što su tablete ili kapsule ${ }^{1}$

Fig. 1 - Plasma drug concentration as a function of time after oral administration of two doses of an oral dosage form with immediate release such as tablet or capsule ${ }^{1}$

Farmaceutske formulacije s kontroliranim/produljenim oslobađanjem pokušavaju postići željenu koncentraciju lijeka u krvi kroz određeno vrijeme, a za njihov razvoj i djelovanje ključnu ulogu imaju jedinstvena fizikalno-kemijska svojstva polimera. To je ujedno i jedno od najvećih područja primjene polimera u modernoj farmaceutskoj industriji. ${ }^{4-9}$ Kod takvih sustava koncentracija djelatne tvari zadržava se u terapijskom području produljeno vrijeme i na taj način znatno smanjuje mogućnost pojavljivanja nuspojava (vidi sliku 2). Postoji nekoliko različitih strategija za formuliranje farmaceutskih oblika lijekova s kontrolira- 


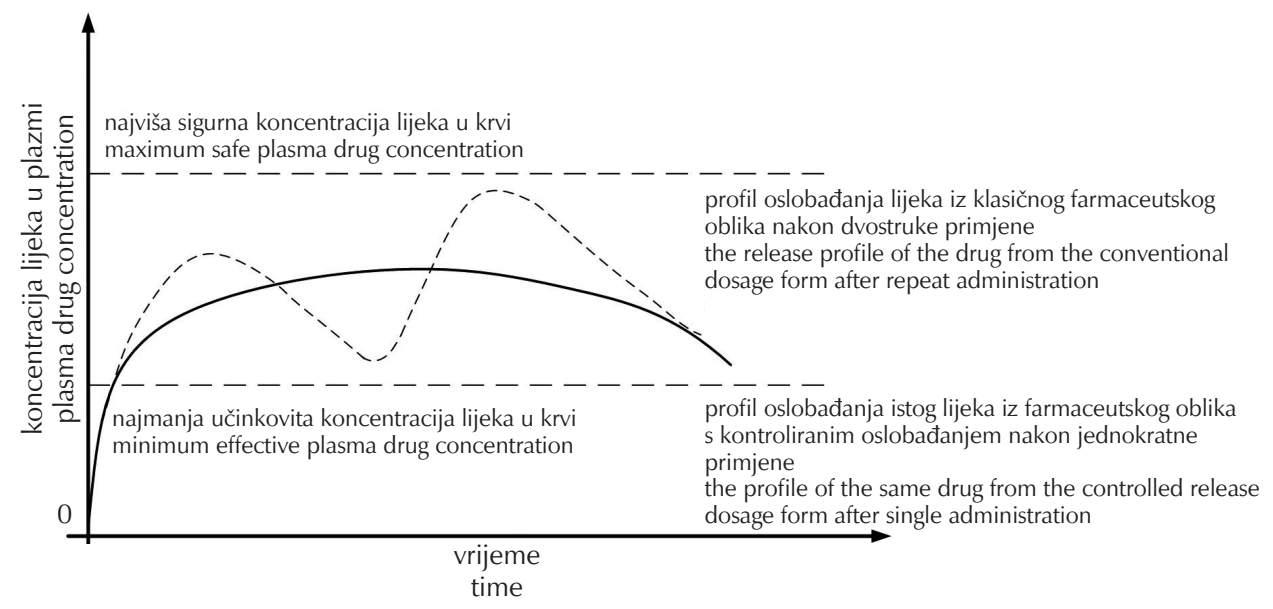

Slika 2 - Koncentracija lijeka u plazmi kao funkcija vremena nakon oralne primjene dvije doze iz klasičnog farmaceutskog oblika kao što su tablete ili kapsule (- - - - -) i nakon jednokratne primjene istog lijeka iz farmaceutskog oblika s kontroliranim oslobađanjem (— $)^{1}$

Fig. 2 - Plasma drug concentration as a function of time after oral administration of two doses of a conventional oral dosage form such as tablet or capsule (- - - - -) and after single administration of the same drug from the controlled release dosage form (

nim oslobađanjem, ali svima je zajedničko da uključuju primjenu polimera. Neki od njih bit će opširnije prikazani u nastavku ovog rada. Glavne prednosti primjene takvih sustava su produljeno vrijeme djelovanja lijeka od jednog tjedna, jednog pa čak i više mjeseci, smanjenje doze lijeka $\mathrm{s}$ istodobnim smanjenjem mogućih neželjenih nuspojava, s ciljem poboljšanja kvalitete života pacijenata. ${ }^{1,2}$

\section{Klasični farmaceutski oblici s trenutnim oslobađanjem}

Unatoč brojnim prednostima farmaceutskih oblika s kontroliranim oslobađanjem, najpopularniji su i dalje klasični farmaceutski oblici kao što su tablete i kapsule te je više od $75 \%$ svih proizvedenih lijekova u svijetu napravljeno za oralnu primjenu. Razlog tome je što se ti farmaceutski oblici mogu povoljno i učinkovito proizvesti, pakirati i transportirati u odnosu na ostale farmaceutske oblike. ${ }^{1,2}$ Izrada klasičnih farmaceutskih oblika podrazumijeva uključivanje polimera kao pomoćnih tvari prilikom proizvodnje, gdje tradicionalno služe kao vezivna sredstva, sredstva za rahljenje, razrjeđivanje, podmazivanje itd. 3,10

\subsection{Tablete}

Tablete kao klasični farmaceutski oblici nastaju komprimiranjem djelatne tvari koja se neposredno umješava ili granulira s pomoćnim tvarima. Za takve sustave polimeri se najviše upotrebljavaju kao pomoćne tvari odnosno kao vezivna sredstva i sredstva za rahljenje. Kao vezivna sredstva polimeri se dodaju kako bi povezali lijek u praškastom obliku prilikom vlažnog granuliranja s ciljem dobivanja tablete zadovoljavajuće tvrdoće koja će biti otporna na sve procesne uvjete. Uglavnom su to polimeri prirodnog podrijetla kao što su škrob i celuloza, a u novije vrijeme i sintetički polimeri kao što je poli(akrilna kiselina) (PAA) ili
poli(N-vinil-pirolidon) (PVP). Sredstva za rahljenje dodaju se s ciljem pospješivanja topljivosti tablete u prisustvu vode tako da dolazi do prevladavanja kohezijskih sila koje vladaju u tableti kao posljedica kompresije. Najpoznatiji polimeri prirodnog podrijetla koji se upotrebljavaju u tu svrhu su također škrob, celuloza te njihovi derivati. ${ }^{1-3}$

\subsection{Kapsule}

Kapsule se također ubrajaju pod klasične farmaceutske oblike, a njihova glavna komponenta je želatina. Ovisno o njezinom sastavu razlikuju se tvrde i meke kapsule. Polimeri se često upotrebljavaju kao dodatak želatini i imaju ulogu punila ili plastifikatora. Fleksibilnost i čvrstoća, kao i brzina oslobađanja lijeka iz kapsule, znatno će ovisiti o udjelu i vrsti polimera koji se doda želatini. Škrob i škrobni derivati često se dodaju kapsulama kao pomoćne tvari. ${ }^{1-3}$

\subsection{Tablete i kapsule obložene polimernom ovojnicom}

Mnoge se tablete i kapsule oblažu tankom polimernom ovojnicom s ciljem zaštite djelatne tvari od vanjskih utjecaja kao što su vlaga, kisik iz zraka te svjetlost, ali i kontrole otpuštanja lijeka kao što je sprječavanje prijevremene razgradnje u ustima kada je tableta u kontaktu sa slinom ili prilikom prolaska kroz probavni sustav. Također, razlozi oblaganja mogu biti u svrhu poboljšanja okusa, izgleda ili mirisa. ${ }^{1,2,11}$ Polimeri koji se upotrebljavaju za izradu film-ovojnica dijele se prema tome jesu li topljivi ili netopljivi u vodi te je li im topljivost uvjetovana vrijednošću pH fiziološkog medija. ${ }^{12,13}$ Najpoznatiji polimeri koji se primjenjuju za oblaganje tableta i kapsula su celuloza i njezini derivati kao primjerice metil-celuloza (MC) i hidroksipropilmetil-celuloza (HPMC) koji su vodotopljivi te etil-celuloza (EC) koja nije topljiva u vodi. ${ }^{1,2}$ Polimeri čija je topljivost uvjetovana vrijednošću pH najčešće su sintetskog 
podrijetla, a najpoznatiji su akrilatni i metakrilatni kopolimeri (slika 3).<smiles>CCCC(C)(C(=O)OCC)C(C)(C)CC(C)(C)C(=O)OCC</smiles>

metakrilna kiselina

etil-metakrilat

methacrylic acid

ethyl methacrylate

Slika 3 - Primjer metakrilatnog kopolimera koji se upotrebljava za oblaganje tableta

Fig. 3 - Example of methacrylic copolymer used for tablet-coating

Njihova topljivost te svojstvo bubrenja mogu se modificirati ugradnjom kationskih i anionskih monomera te njihovim omjerom $u$ odnosu na neutralnu estersku skupinu $u$ kopolimeru. Primjerice, topljivost poli(metakrilne kiseline-Co-metil-metakrilata) kreće se u području $\mathrm{pH}$ od 5.5 do 7.0 ovisno o relativnom omjeru hidrofilne metakrilne kiseline i hidrofobnog metil-metakrilata. Dakle, promjenom kemijskog sastava kopolimera moguće je postići topljivost polimera u željenom području $\mathrm{pH}$. Primjerice, lijekovi koji su nestabilni u kiselom okruženju na taj način mogu se zaštititi od neželjene prijevremene razgradnje u želudcu, a oslobađanje djelatne tvari odvija se u području s višim pH kao što su crijeva. Širok spektar kopolimera koji se upotrebljavaju u tu svrhu poznati su pod komercijalnim nazivom Eudragit ${ }^{\odot}$, a proizvodi ih njemačka tvrtka Evonik Industries. ${ }^{14}$

\section{Farmaceutski oblici s kontroliranim oslobađanjem}

Postoje različito dizajnirani farmaceutski sustavi za dostavu lijeka s kontroliranim oslobađanjem, a glavni mehanizam oslobađanja djelatne tvari može se odvijati: (1) difuzijom kroz matriks ili membranu, (2) otapanjem, (3) erozijom ili biodegradacijom, (4) osmozom i (5) ionskom izmjenom., ${ }^{1,2}$ Kod difuzijski kontroliranih sustava polimer koji nije topljiv u vodi kontrolira ulazak vode u sustav nakon čega otopljene čestice djelatne tvari difundiraju određenom brzinom iz sustava kroz pore polimernog matriksa ili prolaskom između polimernih lanaca. Kada se primjenjuju polimeri koji su topljivi u vodi, njihova brzina otapanja kontrolirat će oslobađanje djelatne tvari. Promjenom debljine polimerne ovojnice kao i njezina sastava može se podesiti brzina oslobađanja lijeka iz tako dizajniranog sustava. Kada je lijek dispergiran u matriksu biorazgradljivog polimera, tada će brzina oslobađanja lijeka iz matriksa biti kontrolirana brzinom degradacije polimera. Sustavi gdje je osmoza glavni pokretački mehanizam upotrebljavaju tzv. osmotske komponente koje imaju moć upijanja vode kroz polupropusnu membranu. Pri tome dolazi do porasta tlaka u sustavu zbog kojeg dolazi do istiskivanja djelatne tvari kroz otvor točno definirane veličine. Brzina oslobađanja djelatne tvari može se modificirati veličinom otvora i promjenom vrste tzv. osmotske komponente. Ionska izmjena je mehanizam koji se primjenjuje za postizanje kontroliranog oslobađanja djelatne tvari koja je u obliku kompleksa vezana na polimerni nosač koji se cijepa u organizmu te oslobađa lijek na željenom mjestu. ${ }^{4,5,8,9}$

Kod većine terapijskih sustava, nije zastupljen samo jedan mehanizam, nego njih više, ali jedan od njih može biti dominantan. U svim slučajevima, polimeri imaju funkcionalnu ulogu i kontroliraju transport molekule lijeka, a način na koji je to postignuto u sklopu sustava za dostavu lijeka odredit će primarni mehanizam. Prema tome, razlikuje se nekoliko izvedbi sustava za dostavu lijeka s kontroliranim oslobađanjem, a u nastavku ovog rada detaljnije će biti opisani: (1) spremišni sustavi, (2) matriksni sustavi, (3) osmotski sustavi, (4) transdermalni sustavi i (5) napredni farmaceutski sustavi na bazi hidrogelova osjetljivih na fizikalne i kemijske vanjske pobude. ${ }^{15,16}$

\subsection{Spremišni sustavi}

Kod spremišnih sustava lijek odnosno čestice lijeka obložene su polimernom ovojnicom ili polimernom membranom (slika 4), te je na taj način oslobađanje lijeka najvećim dijelom kontrolirano svojstvima polimera kao što su njihov kemijski sastav i molekulske mase te debljina tog polimernog sloja. ${ }^{1,17,18}$

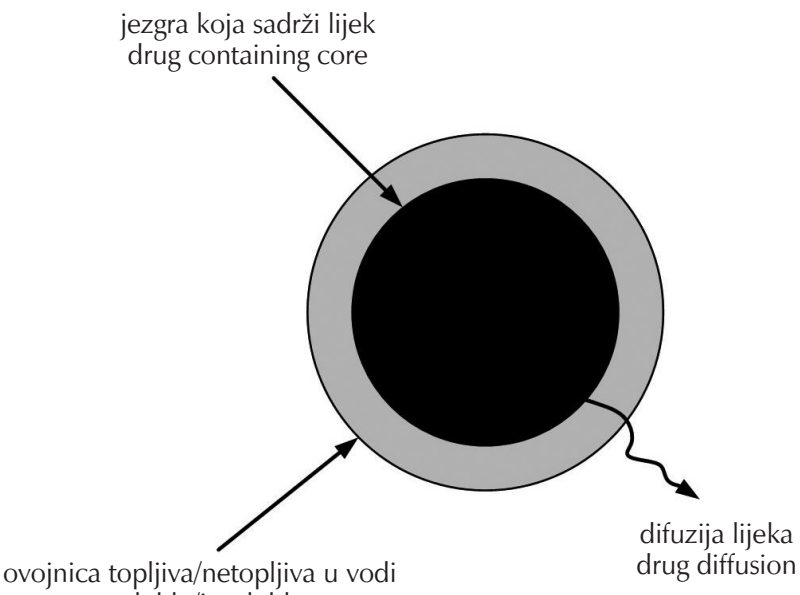

water soluble/insoluble core

Slika 4 - Shematski prikaz spremišnog sustava za kontrolirano oslobađanje lijeka ${ }^{1}$

Fig. 4 - Schematic representation of a reservoir controlled release system

Na taj način, osigurano je otpuštanje lijeka kroz određeno razdoblje, pri čemu je koncentracija djelatne tvari konstantna (kinetika nultog reda). Spremišni sustavi obuhvaćaju razne oblike farmaceutskih pripravaka od klasičnih tableta do sofisticiranih oblika kao što su mikro/nanočestice te implantanti. ${ }^{17}$

Polimeri koji se upotrebljavaju za razvoj takvih farmaceutskih oblika mogu se podijeliti u dvije skupine ovisno o mehanizmu oslobađanja djelatne tvari: a) polimere koji nisu 
biorazgradljivi, gdje je oslobađanje kontrolirano difuzijom djelatne tvari i b) biorazgradljive polimere, gdje je oslobađanje kontrolirano erozijom polimerne ovojnice (vidi sliku 5). 17,19

tableta obložena polimernom ovojnicom coated tablet
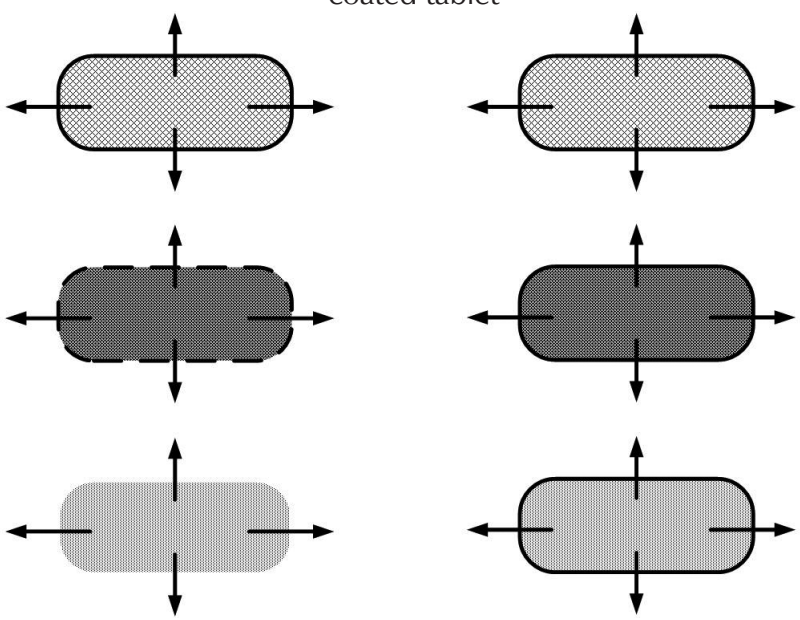

topljivi i biorazgradljivi polimer soluble/erodible polymer

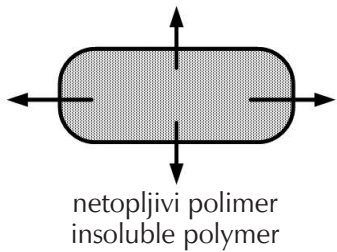

Slika 5 - Shematski prikaz oslobađanja lijeka iz tableta obloženih topljivim/erozivnim i netopljivim polimerima ${ }^{19}$

Fig. 5 - Schematic representation of release behaviour of coated tablets with soluble/erodible or insoluble polymers ${ }^{19}$

\subsubsection{Bionerazgradljivi polimeri}

Bionerazgradljivi polimeri upotrebljavaju se kod sustava gdje je oslobađanje kontrolirano difuzijom lijeka. Kod tako dizajniranih sustava oslobađanje lijeka kontrolirano je debljinom polimerne ovojnice i topljivošću djelatne tvari. Najčešće se upotrebljavaju silikonski polimeri odnosno linearni i umreženi poli(dimetilsiloksan) - PDMS, umreže- ni poli(vinil-alkohol) - PVAL i poli(etilen-co-vinil-acetat) EVAC (vidi tablicu 1). ${ }^{17} \mathrm{Ti}$ su polimeri odobreni od strane američke agencije FDA (engl. Food and Drug Administration) jer je dokazano da nemaju štetan utjecaj na ljudski organizam. EVAC je nepropustan polimer za mnoge djelatne tvari te se najčešće upotrebljava kao membrana formirana oko jezgre lijeka s ciljem smanjenja brzine otpuštanja lijeka u određenom vremenu. ${ }^{17} \mathrm{~S}$ druge strane, PVAL je propustan polimer za mnoge lipofilne lijekove te se najčešće upotrebljava kao propusna membrana u području otpuštanja lijeka. Debljina sloja PVAL-a može se prilagoditi kako bi se postigla željena kinetika oslobađanja lijeka. ${ }^{17}$ Silikonski polimeri mogu biti propusni i nepropusni ovisno o debljini sloja te njihovoj vrsti i kvaliteti. ${ }^{5-7}$ Razvijeno je nekoliko implantata s bionerazgradljivim polimerima za liječenje očnih bolesti. ${ }^{20,21}$

Također, u razvoju je velik broj sustava za dostavu lijeka koji uključuju razne bločne i linearne kopolimere na bazi akrilata i metakrilata koji se upotrebljavaju za izradu filmova i ovojnica za oblaganje tableta. ${ }^{22}$

\subsubsection{Biorazgradljivi polimeri}

Biorazgradljivi polimeri pronašli su veliku primjenu u ovom području. Prema podrijetlu razlikujemo dvije vrste biorazgradljivih polimera: prirodne i sintetičke polimere. ${ }^{17} \mathrm{Od}$ prirodnih polimera najviše se primjenjuju proteini kao primjerice kolagen i želatina te polisaharidi (škrob, celuloza, kitozan, dekstran itd.). Primjena kolagena i želatine vrlo je raširena kod sustava s kontroliranim oslobađanjem lijeka. Primjerice, kolagen ima brojne prednosti kao što su biokompatibilnost i netoksičnost. Međutim kolagen istodobno ima vrlo loša mehanička svojstva te poteškoće u postizanju dobre ponovljivosti profila oslobađanja lijeka, a ustanovljeno je i da neki pacijenti imaju imunogenu reakciju na kolagen što znatno ograničava njegovu primjenu. ${ }^{17,23}$ Želatina je termoreverzibilan polimer. ${ }^{17}$ Također ima široku primje-

Tablica 1- Kemijska struktura sintetičkih bionerazgradljivih polimer

Table 1 - Chemical structure of synthetic non-biodegradable polymers

\begin{tabular}{|c|c|c|}
\hline $\begin{array}{l}\text { Naziv polimera } \\
\text { Polymer name }\end{array}$ & $\begin{array}{l}\text { Kemijska struktura } \\
\text { Chemical structure }\end{array}$ & $\begin{array}{l}\text { Referencije } \\
\text { Reference }\end{array}$ \\
\hline $\begin{array}{l}\text { poli(dimetilsiloksan) } \\
\text { polydimethylsiloxane }\end{array}$ & $-{ }_{1}^{\mathrm{Si}}-\mathrm{O}+\underset{\mathrm{I}}{\mathrm{Si}}-\mathrm{O}+\underset{n \mid}{\mathrm{Si}}$ & 1,2 \\
\hline $\begin{array}{l}\text { poli(vinil-alkohol) } \\
\text { poly(vinyl alcohol) }\end{array}$ & {$\left[\begin{array}{r}\mathrm{CH}_{2}-\mathrm{CH}+ \\
\mathrm{O} \\
\mathrm{OH}\end{array}\right]_{n}$} & 1,2 \\
\hline $\begin{array}{l}\text { poli(etilen-co-vinil-acetat) } \\
\text { poly(ethylene-co-vinyl acetate) }\end{array}$ & 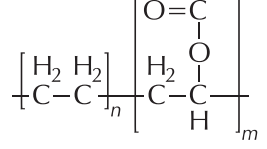 & 1,2 \\
\hline
\end{tabular}


nu jer je lako dostupan, a sposobnost vezivanja za molekule lijeka vrlo mu je mala. Sintetički biorazgradljivi polimeri s najširom primjenom su polilaktid (PLA), poliglikolid (PGA), poli(laktid-co-glikolid) - PLGA, polikaprolakton - PCL, poli(orto-esteri), polianhidridi itd. (vidi tablicu 2). ${ }^{17}$ Od svih navedenih, PLA, PGA i njihov kopolimer PLGA različitog kemijskog sastava najviše su primjenjivani te najbolje istraženi. Monomeri za proizvodnju kopolimera PLGA proizvode se iz mliječne i glikolidne kiseline koje se dobivaju iz biomase odnosno kukuruznog škroba i šećerne trske, što je velika prednost u odnosu na ostale sintetske polimere koji se proizvode iz naftnih derivata. Karakteristike kopolimera PLGA vrlo dobro odgovaraju potrebama farmaceutskih proizvoda kao što su biokompatibilnost s ljudskim organizmom, a i njihovi degradacijski produkti, mliječna i glikolidna kiselina vrlo se lako prirodnim putem mogu eliminirati iz ljudskog organizma. ${ }^{17,24-26}$ PLA, PGA i PLGA upotrebljavaju se za dobivanje mikročestica kao terapijskih sustava za liječenje raznih bolesti. Također, upotrebljavaju se i kod razvoja terapijskih sustava na bazi peptida jer mogu zaštititi djelatnu tvar od enzimskih napada. ${ }^{5-7,17}$

Lupron Depot, Zoladex i Decapeptyl primjeri su peptidnih lijekova odobrenih od američke agencije FDA u kojima se upotrebljavaju kopolimeri PLGA. ${ }^{30} \cup$ tablici 3 dan je pregled farmaceutskih proizvoda s kontroliranim produljenim oslobađanjem odobrenih od strane FDA, a na bazi kopolimera PLGA. ${ }^{30}$

Nekoliko je svjetskih tvrtki kao primjerice PR Pharmaceutical i StarPharma razvilo sustave za dostavu lijeka, gdje je lijek pakiran u biorazgradljivom polimernom matriksu u obliku mikročestica ili nanočestica. ${ }^{17} \mathrm{Na}$ taj način lijek se postupno oslobađa iz biorazgradljivog matriksa, što znatno smanjuje mogućnost nuspojava, a ujedno se i povećava usklađenost i učestalost primjene lijeka sa željama pacijenta. ${ }^{17}$ Brzina oslobađanja lijeka iz sustava koji se koriste biorazgradljivim polimerima kontrolirana je najvećim dijelom brzinom degradacije polimera. ${ }^{17}$

Postoje dva načina na koji polimerni matriks degradira, a to je unutarnja i površinska erozija (slika 6). Kod površinske
Tablica 2- Kemijska struktura sintetičkih biorazgradljivih polimera

Table 2 - Chemical structure of synthetic biodegradable polymers

\begin{tabular}{|c|c|c|}
\hline $\begin{array}{l}\text { Naziv polimera } \\
\text { Polymer name }\end{array}$ & $\begin{array}{l}\text { Kemijska struktura } \\
\text { Chemical structure }\end{array}$ & $\begin{array}{c}\text { Referencije } \\
\text { Reference }\end{array}$ \\
\hline $\begin{array}{l}\text { poliesteri } \\
\text { polyesters } \\
\text { (PLA, PLGA) }\end{array}$ & & $25,26,30,33$ \\
\hline $\begin{array}{l}\text { polikaprolakton } \\
\text { polycaprolactone }\end{array}$ & & 27,33 \\
\hline $\begin{array}{l}\text { polianhidridi } \\
\text { polyanhydrides }\end{array}$ & & 28,33 \\
\hline $\begin{array}{l}\text { poli(orto-esteri) } \\
\text { polyorthoesters }\end{array}$ & POE I & 29,33 \\
\hline
\end{tabular}

erozije brzina hidrolize polimernih lanaca znatno je veća od prodora vode u unutrašnjost matriksa zbog čega matriks progresivno nestaje s površine. Kod unutarnje erozije polimerni lanci sporije erodiraju, a ulazak vode u matriks znatno je brži. U tom slučaju matriks ne mijenja znatno svoje dimenzije sve dok se nije potpuno razgradio, a produkti degradacije polimera postupno s vremenom napuštaju matriksni sustav. Kod te vrste degradacije može doći do pojave autoakceleracije odnosno učinka uzrokovanog akumulacijom degradacijskih produkata u polimernom matriksu koji ubrzavaju degradacijski proces. ${ }^{17}$ Upravo iz tog razloga, na početku, a i kasnije, može doći do nekontroliranog oslobađanja lijeka iz tako dizajniranog sustava. Raznim modifikacijama polimernog matriksa, ali i cijelog sustava, kontinuirano se pokušava umanjiti utjecaj pojave nekontroliranog oslobađanja lijeka te postizanja kinetike oslobađanja lijeka pseudonultog reda. ${ }^{1,31-34}$

Tablica 3- Popis farmaceutskih proizvoda s kontroliranim/produljenim oslobađanjem djelatne tvari odobrenih od strane FDA, a u kojima se upotrebljavaju biorazgradljivi kopolimeri PLGA 30

Table 3 - List of FDA approved pharmaceutical long acting release products that uses biodegradable PLGA copolymers ${ }^{30}$

\begin{tabular}{|c|c|c|c|c|}
\hline $\begin{array}{l}\text { Naziv proizvoda } \\
\text { Name of the product }\end{array}$ & $\begin{array}{l}\text { Lijek } \\
\text { Drug }\end{array}$ & $\begin{array}{l}\text { Tvrtka } \\
\text { Company }\end{array}$ & $\begin{array}{l}\text { Doziranje } \\
\text { Dosing }\end{array}$ & $\begin{array}{l}\text { Indikacije } \\
\text { Indication }\end{array}$ \\
\hline Risperdal Consta & $\begin{array}{l}\text { risperidon } \\
\text { risperidone }\end{array}$ & $\begin{array}{l}\text { Janssen } \\
\text { Alkermes }\end{array}$ & $\begin{array}{l}1 \text { mjesec } \\
1 \text { month }\end{array}$ & $\begin{array}{l}\text { šizofrenija } \\
\text { schizophrenia }\end{array}$ \\
\hline Eligard & leuprolid & QLT & $\begin{array}{l}1,3,4,6 \text { mjeseci } \\
1,3,4,6 \text { months }\end{array}$ & $\begin{array}{l}\text { rak prostate } \\
\text { prostate cancer }\end{array}$ \\
\hline Bydureon & exenatide & $\begin{array}{l}\text { Amylin/BMS } \\
\text { Alkermes }\end{array}$ & $\begin{array}{l}1 \text { tjedan } \\
1 \text { week }\end{array}$ & $\begin{array}{l}\text { dijabetes tipa } 2 \\
\text { type } 2 \text { diabetes }\end{array}$ \\
\hline Zoladex & goserelin & AstaZeneca & $\begin{array}{l}\text { 1,3 mjeseca } \\
\text { 1,3 months }\end{array}$ & $\begin{array}{l}\text { rak prostate } \\
\text { prostate cancer }\end{array}$ \\
\hline Sandostatin LAR & octreotide & Novartis & $\begin{array}{l}1 \text { mjesec } \\
1 \text { month }\end{array}$ & $\begin{array}{l}\text { akromegalija } \\
\text { acromegaly }\end{array}$ \\
\hline
\end{tabular}


a) površinska erozija surface erosion
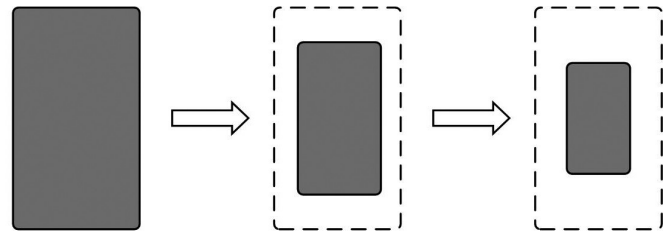

b) unutarnja erozija bulk erosion
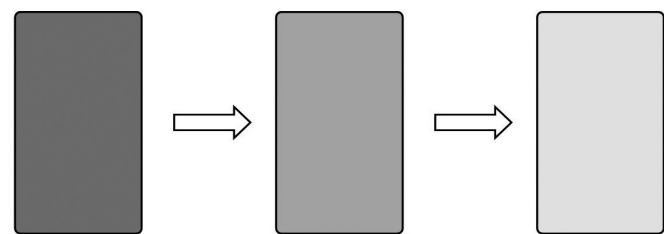

Slika 6 - Shematski prikaz a) površinske i b) unutarnje erozije polimernog matriksa ${ }^{33}$

Fig. 6 - Schematic illustration of a) surface and b) bulk erosion of polymer matrix ${ }^{33}$

\subsection{Matriksni sustavi}

U matriksnom sustavu lijek je jednoliko raspoređen (dispergiran) unutar polimernog matriksa tako da se oslobađanje lijeka odvija difuzijom kroz pore polimernog matriksa ili između umreženih polimernih lanaca (vidi sliku 7). ${ }^{1,2}$

Najvažnija svojstva polimera koji se upotrebljavaju za pripravu takve vrste farmaceutskih oblika su njihova topljivost u vodi te svojstvo bubrenja. ${ }^{35,36} \mathrm{U}$ tablici 4 sumirani su neki primjeri. Ovisno o tome kakvu vrstu polimera upotrebljavamo, razlikovat će se i mehanizam oslobađanja lijeka (vidi sliku 8). Polimeri koji upijaju vodu ne otapaju se trenutno, već postupno bubre, pri čemu dolazi do relaksacije polimernih lanaca. Posljedično, smanjuje se temperatura staklastog prijelaza polimera $\left(T_{\mathrm{g}}\right)$ te polimer prelazi iz staklastog u viskoelastično (gumasto) stanje, pri čemu polimerni lanci postaju fleksibilniji, što rezultira promjenom konformacije makromolekule i dovodi do stvaranja tzv. geliranog sloja. Lijek koji je topljiv u vodi difundira kroz gelirani sloj polimernih lanaca, a lijek koji je netopljiv u vodi postupno lijek dispergiran u matriksu drug dispersed in matrix

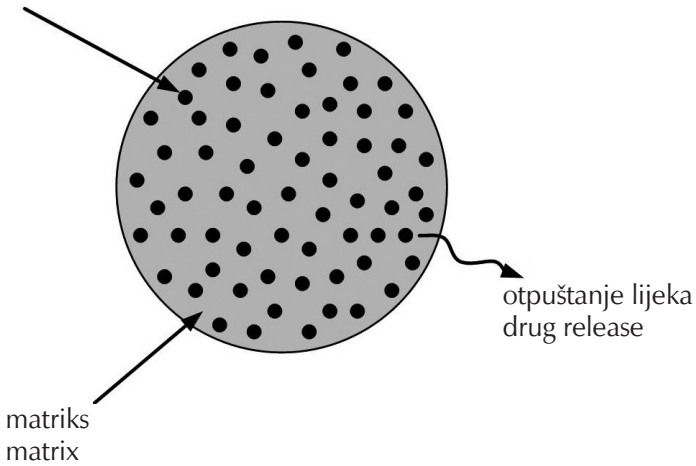

Slika 7 - Shematski prikaz matriksnog sustava za kontrolirano oslobađanje lijeka ${ }^{1}$

Fig. 7 - Schematic representation of a matrix controlled release system $^{1}$

se oslobađa erozijom polimernog matriksa. U tom slučaju mehanička svojstva gela ključan su parametar koji kontrolira oslobađanje lijeka, a znatno ovisi o svojstvima polimera kao što je njegov kemijski sastav, molekulska masa te međumolekulske interakcije s otapalom, djelatnom tvari i ostalim pomoćnim tvarima u formulaciji. ${ }^{37,38}$

Kod polimera koji ne upijaju vodu i ne bubre dolazi do močenja površine polimernog matriksa koja postupno erodira i ne stvara se gelirani sloj. Na taj način čestice lijeka postupno izlaze iz matriksa isključivo zbog površinske erozije. U tom slučaju dimenzije farmaceutskog oblika znatno se smanjuju. Kada se upotrebljavaju polimeri koji nisu topljivi u vodi, medij penetrira u matriks tijekom čega dolazi do otapanja lijeka koji onda difundira kroz polimerni matriks. Matriks se neće mijenjati dimenzijski kod polimera koji ne bubre, a kod onih koji bubre doći će postupno do njegove ekspanzije (vidi sliku 8). Ista vrsta biorazgradljivih polimera koji se upotrebljavaju u spremišnim sustavima, upotrebljava se i u matriksnim sustavima za dostavu lijeka. ${ }^{35-38}$

Tablica 4- Popis polimera koji se upotrebljavaju u matriksnim sustavima i njihova svojstva Table 4 - List of polymers used in matrix systems and their properties

\begin{tabular}{l|l|l|l}
\hline \multicolumn{2}{l|}{$\begin{array}{l}\text { Svojstva polimera } \\
\text { Polymer properties }\end{array}$} & $\begin{array}{l}\text { Primjeri } \\
\text { Examples }\end{array}$ & $\begin{array}{l}\text { Referencije } \\
\text { Reference }\end{array}$ \\
\hline \multirow{2}{*}{$\begin{array}{l}\text { topljivi/erozivni } \\
\text { soluble/erodible }\end{array}$} & $\begin{array}{l}\text { bubre } \\
\text { swellable }\end{array}$ & $\begin{array}{l}\text { hidroksipropilmetil-celuloza } \\
\text { hydroxypropylmethylcellulose } \\
\text { poli(etilen-oksid) } \\
\text { poly(ethylene oxide) }\end{array}$ & $\mathbf{1 , 2 , 3 5 , 3 6}$ \\
\cline { 2 - 4 } & $\begin{array}{l}\text { ne bubre } \\
\text { non-swellable }\end{array}$ & $\begin{array}{l}\text { poli(vinil-pirolidon) } \\
\text { poly(vinyl pirolidon) } \\
\text { hidroksipropil-celuloza } \\
\text { hydroxypropylcellulose }\end{array}$ & $\mathbf{1 , 2 , 3 5 , 3 6}$ \\
\hline \multirow{2}{*}{$\begin{array}{l}\text { netopljivi } \\
\text { insoluble }\end{array}$} & $\begin{array}{l}\text { bubre } \\
\text { swellable }\end{array}$ & $\begin{array}{l}\text { ethyl cellulose } \\
\text { celulozni acetat } \\
\text { cellulose acetate }\end{array}$ & $\mathbf{1 , 2 , 3 5 , 3 6}$ \\
\cline { 2 - 4 } & $\begin{array}{l}\text { ne bubre } \\
\text { non-swellable }\end{array}$ & $\begin{array}{l}\text { eudragit rs (metakrilni kopolimeri) } \\
\text { eudragit rs (metacrylic } \\
\text { copolymers) }\end{array}$ & $\mathbf{1 , 2 , 3 5 , 3 6}$ \\
\hline
\end{tabular}




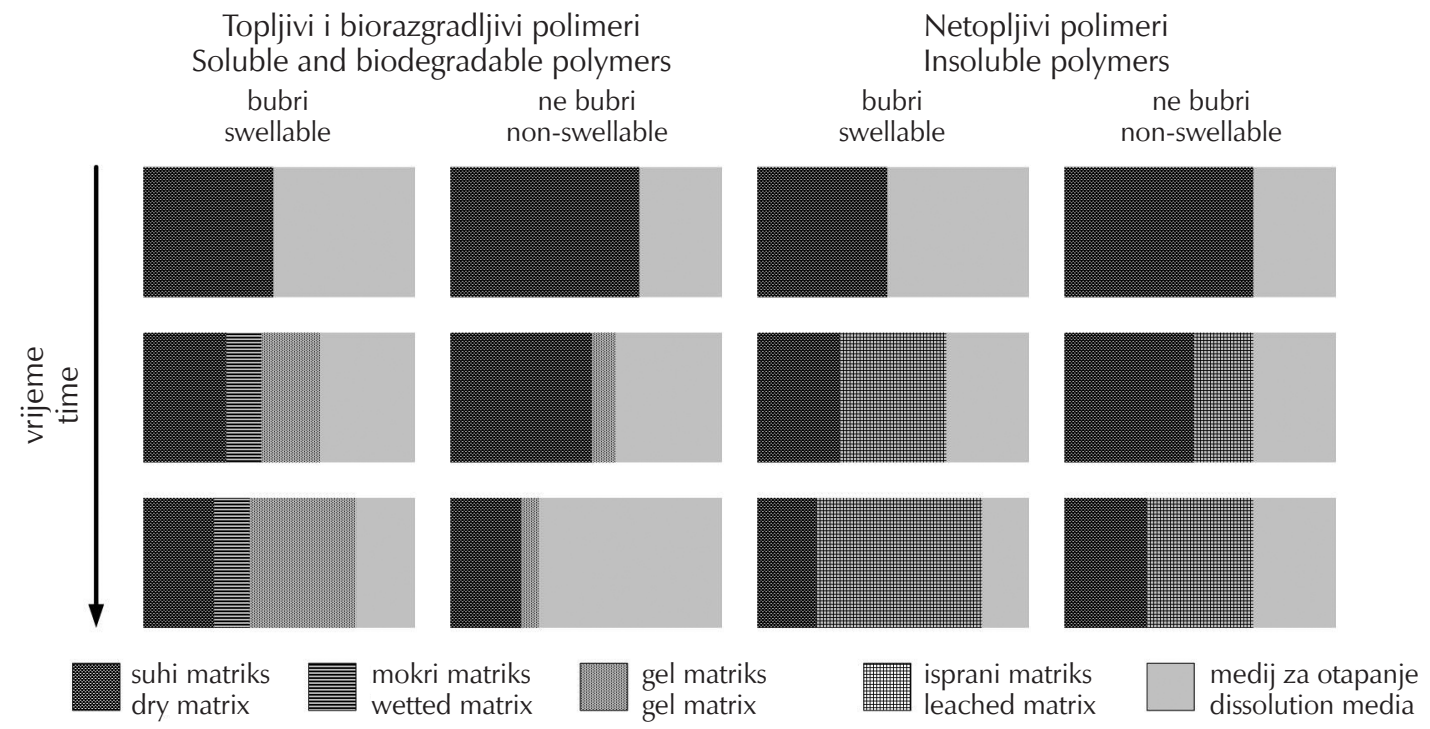

Slika 8 - Shematski prikaz pomicanja fronta kod različitih matriksnih sustava ${ }^{38}$

Fig. 8 - Schematic representation of front movement in different types of matrices ${ }^{38}$

\subsection{Osmotski sustavi}

Osmotski sustavi odnosno sustavi koji se koriste osmotskim tlakom za dostavu lijeka napredno su dizajnirani sustavi za kontrolu oslobađanja lijeka, a nazivaju se još i osmotske pumpe. ${ }^{1,4} \mathrm{U}$ takvim sustavima lijek je u jezgri zaštićen polimernom ovojnicom koja propušta vodeni medij iz okoline, a zatim se otopina lijeka istiskuje pomoću osmotskoga tlaka obično kroz mali otvor u polimernoj ovojnici koji omogućava konstantno ispuštanje lijeka tijekom vremena. Polimerna ovojnica u osmotskim sustavima ima točno određenu propusnost, te je na taj način određena brzina oslobađanja lijeka te njegova koncentracija u određenom vremenskom okviru. Tako dizajnirani sustavi prikladni su za lijekove srednje topljivosti. Osmotski sustavi dizajnirani za lijekove s ekstremnom topljivošću, uz polupropusnu membranu imaju još u donjem dijelu dodatni sloj polimera koji bubri te promjenom svojeg volumena istiskuje lijek iz sustava (tzv. sustavi "push-pull", vidi sliku 9). ${ }^{39}$ Svojstva polupropusne membrane ključna su prilikom postizanja kontroliranog oslobađanja lijeka iz takvih sustava. Membrane u osmotskim sustavima građene su od polimera koji su selektivno propusni za vodu, a nepropusni za otopinu lijeka. To su uglavnom celulozni esteri i eteri te njihovi derivati, a najpoznatiji su celulozni acetat i etil-celuloza. ${ }^{40,41}$

\subsection{Transdermalni sustavi (flasteri)}

Transdermalni sustavi primjenjuju se za kontrolirano oslobađanje, gdje lijek difundira kroz kožu, a apsorbira se u sistemsku cirkulaciju pacijenta. ${ }^{1}$ Takvi sustavi primjenjuju se kod lijekova niske topljivosti, a služe za suzbijanje boli, prestanak pušenja, hormonalne terapije, liječenje srčanih bolesti itd. ${ }^{1} \mathrm{~S}$ obzirom na to da je glavna funkcija kože da štiti organizam od prodora štetnih tvari, vrlo je mali broj djelatnih tvari koje imaju odgovarajuća fizikalno-kemijska svojstva da mogu proći tu anatomsku barijeru. Naime, lijek mora proći tri sloja kože prije nego što dospije u krvotok,

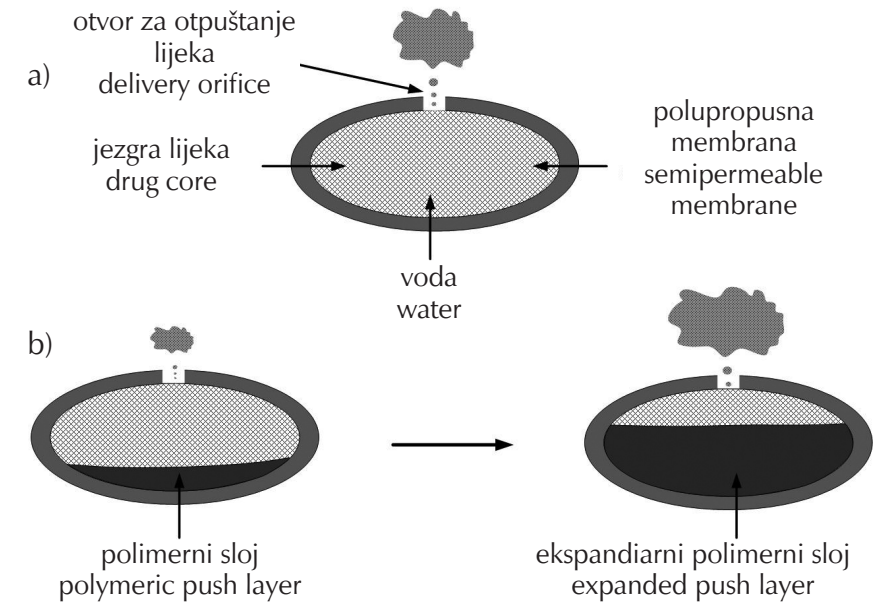

Slika 9 - Shematski prikaz a) osnovnog osmotskog sustava i b) tzv. osmotskog sustava push-pull ${ }^{40}$

Fig. 9 - Schematic representation of a) elementary osmotic system and b) "push-pull" osmotic system ${ }^{40}$

a to su stratum comeum (gornji vanjski sloj kože), epidermis i dermis. lako sva tri sloja pružaju otpor difuziji lijeka, najzahtjevniji je stratum comeum, u kojem su nakupine mrtvih stanica pakirane u manje blokove. Taj je sloj vrlo lipofilan te je difuzijski put čestica obilježen brojnim lutanjima. Nakon prolaska kroz stratum comeum lijek dolazi u više hidrofilno područje epidermisa i dermisa prije nego se apsorbira i dospije u sistemsku cirkulaciju. ${ }^{4}$

Glavne prednosti tako dizajniranih sustava su praktičnost primjene te kontrolirano i dugotrajno oslobađanje lijeka. Polimeri čine sastavni dio transdermalnih terapijskih sustava, a mogu se upotrebljavati za izradu zaštitnog vanjskog pokrova koji fizički štiti djelatnu tvar od nepovoljnih vanjskih utjecaja ili oštećenja. ${ }^{1}$ Također, djelatna tvar može biti 
otopljena ili dispergirana u polimernom matriksu koja služi za kontrolirano oslobađanje lijeka kroz kožu. ${ }^{1}$ Osim toga, transdermalni sustavi imaju adhezivni sloj koji služi za održavanje farmaceutskog oblika lijeka na mjestu primjene. ${ }^{1} \mathrm{U}$ nekim izvedbama, adhezivni sloj može dodatno poslužiti i kao spremnik lijeka. Adhezivi koji se primjenjuju u transdermalnim flasterima sadržavaju akrilate, poliizobutilene i silikone. ${ }^{1}$ Transdermalni sustavi mogu biti dizajnirani kao spremišni ili matriksni, a tipičan primjer jednog transdermalnoga spremišnog sustava prikazan je na slici 10. Odabir polimera te njihova fizikalno-kemijska svojstva vrlo su važni kod dizajniranja takvih sustava za dostavu lijeka, jer razne varijacije omogućavaju brojne modifikacije prilikom postizanja željene brzine oslobađanja lijeka. ${ }^{42,43}$

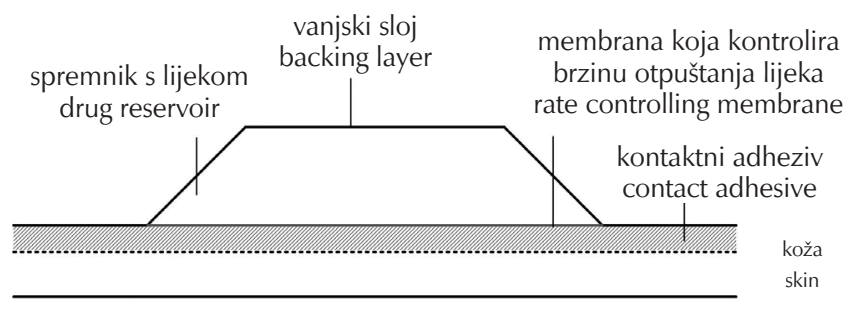

Slika 10 - Shematski prikaz transdermalnog spremišnog sustava s membranom koja kontrolira brzinu otpuštanja lijeka ${ }^{43}$

Fig. 10 - Schematic representation of transdermal reservoir system with rate controlling membrane ${ }^{43}$

\subsection{Sustavi s kontroliranim oslobađanjem lijeka na bazi hidrogelova}

Gelovi su polimerni sustavi koji nastaju fizikalnim ili kemijskim umrežavanjem polimernih lanaca što dovodi do stvaranja porozne trodimenzionalne strukture (vidi sliku 11). Gelovi koji imaju veliku moć upijanja vode prilikom čega se ne otapaju, nego bubre nazivaju se hidrogelovi. Upotreba hidrogelova na bazi polimera u naprednim terapijskim sustavima s kontroliranim oslobađanjem lijeka sve je veća i sve se više primjenjuje u modernoj farmaceutskoj industriji. ${ }^{1,44-46}$

Razlog tome je što hidrogelovi imaju zanimljiva svojstva kao što su pseudoplastično ponašanje, sposobnost upijanja i vezanja vode, bubrenje, biorazgradljivost itd. Dodatno, hidrogelovi s obzirom na svoju konzistentnost nalikuju prirodnom tkivu čovjeka više od bilo kojih drugih sintetičkih biomaterijala zbog čega su pronašli veliku primjenu i u biomedicinskom području kod dizajniranja i izrade umjetnog tkiva, umjetne kože, obloga za umjetno srce, membrana za biosenzore, kontaktne leće itd. ${ }^{48-56}$

Fizikalno umrežavanje hidrogelova, ovisno o vrsti polimera, može biti potaknuto promjenom $\mathrm{pH}$, temperature, ionske jakosti te raznim drugim fizikalnim interakcijama kao što su hidrofobne interakcije, vodikove veze, formiranje stereokompleksa itd. Kemijsko umrežavanje obuhvaća kovalentno povezivanje polimernih lanaca. Stvaranje trodimenzionalne mreže hidrogela omogućeno je prisustvom

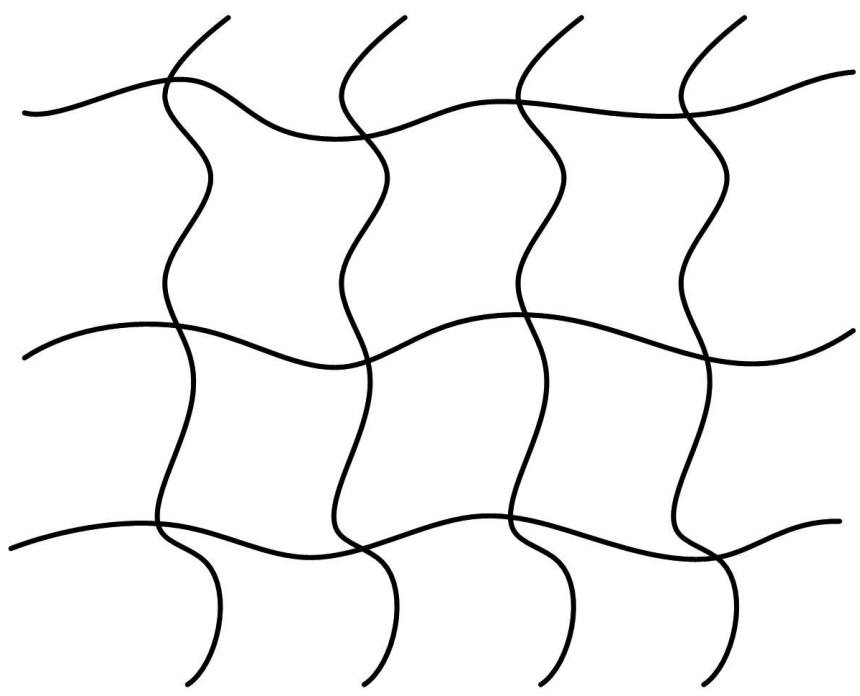

Slika 11 - Shematski prikaz 3D-porozne strukture hidrogelova Fig. 11 -Schematic representation of 3D porous network of hydrogels

hidrofilnih funkcionalnih skupina $\mathrm{u}$ njihovoj strukturnoj građi kao što su $-\mathrm{OH},-\mathrm{COOH},-\mathrm{CONH}_{2} \mathrm{i}-\mathrm{SO}_{3} \mathrm{H}$ koje imaju sposobnost apsorbiranja vode, pri čemu bubre, a ne dolazi do otapanja polimernih lanaca. ${ }^{59}$ Glavne karakteristike hidrogelova koje određuju njihovu primjenu su njihova morfološka i mehanička svojstva te bubrenje. Morfološka svojstva odnose se na njihovu poroznu strukturu koja može biti mikroporozna, makroporozna te superporozna. Stupanj bubrenja određuje mehanizam oslobađanja lijeka iz polimernog matriksa, dok mehanička svojstva formirane 3D-mreže određuju postojanost cjelokupnog sustava za dostavu lijeka, ali i kompatibilnost s okolnim tkivom na mjestu primjene. ${ }^{45}$ Prilikom dizajniranja sustava za dostavu lijeka na bazi hidrogelova upotrebljavaju se biorazgradljivi i tzv. pametni polimeri.

\subsubsection{Biorazgradljivi i pametni polimeri}

Velik broj biorazgradljivih polimera kao što su polilaktid (PLA) i poli(laktid-CO-glikolid) (PLGA) ima sposobnost formiranja trodimenzionalne (3D) porozne strukture hidrogelova. U takvim sustavima oslobađanje djelatne tvari odvija se difuzijom lijeka kroz polimerni matriks hidrogela i postupnom degradacijom polimernog matriksa koja se odvija hidrolizom (vidi sliku 12). ${ }^{57}$

Široku primjenu pronašli su i sustavi za dostavu lijeka na bazi hidrogelova koji upotrebljavaju tzv. pametne polimere odnosno polimere koji reagiraju na fizikalne, kemijske i biološke podražaje iz okoline kao što je temperatura, $\mathrm{pH}$, ionska jakost, redoks potencijal, ultrazvuk itd., te na taj način potiču i kontroliraju oslobađanje lijeka iz polimernog matriksa. Ovisno o vrsti polimera te kojom vanjskom pobudom će biti potaknuto formiranje hidrogela i njegovo bubrenje, razlikuje se nekoliko različitih mehanizama oslobađanja lijeka iz tako dizajniranih sustava (vidi tablicu 5)..$^{1,45,58}$ 
<smiles>CSC(C)OC(=O)C(C)OC(=O)C(C)OC(C)C(=O)OC(C)C(=O)[O-]</smiles>

karakteristika takvih sustava je da mehanizam formiranja hidrogelova može biti potpuno reverzibilan (slika 13). ${ }^{73}$<smiles>CSC(C)OC(=O)C(C)OC(=O)C(C)(O)C(C)(O)C(=O)OC(C)C(=O)O</smiles>

$\mathrm{HO}^{\prime}$<smiles>CC(OC(=O)C([SiH3])OC(C)(C)C(=O)O)C(=O)[As](C)O</smiles>

Slika 12 - Hidrolitičko cijepanje esterskih veza kod polilaktida (PLA)

Fig. 12 - Hydrolysis and cleavage of the ester linkage in polylactide (PLA)

Primjerice, u većini slučajeva oslobađanje lijeka počinje kad je gel već znatno nabubrio ili tijekom procesa bubrenja tako da je kinetika oslobađanja lijeka kontrolirana brzinom bubrenja gela, difuzijom lijeka ili kombiniranim mehanizmom bubrenja i difuzije. Druga vrlo zanimljiva

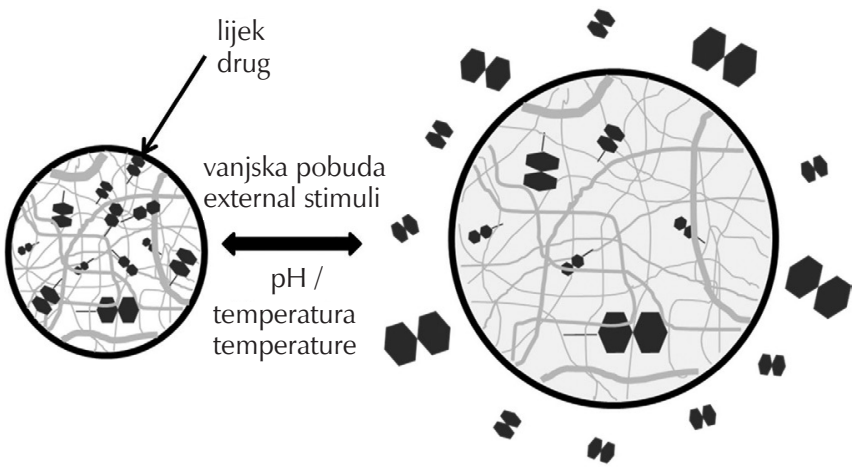

Slika 13 - Bubrenje mrežaste strukture hidrogela potaknuto vanjskom pobudom ( $\mathrm{pH}$, temperatura) i oslobađanje lije$\mathrm{ka}^{73}$

Fig. 13 - Swelling of crosslinked structure of hydrogel triggered with external stimuli ( $\mathrm{pH}$, temperature) and release of the drug $^{73}$

Svojstvo tih sustava da vrlo brzo promijene svoju strukturu s obzirom na vanjske pobude vodi do poželjnih svojstava takvih sustava za primjenu u sustavima za dostavu lijeka kao što su proteini i peptidi. ${ }^{74} \mathrm{U}$ nastavku kratko će biti predstavljeni temperaturno i $\mathrm{pH}$ osjetljivi polimerni sustavi za dostavu lijekova na bazi hidrogelova.

Tablica 5- Popis raznih vanjskih pobuda koje dovode do formiranja hidrogela i oslobađanja lijeka iz umreženog polimernog matriksa $^{59}$

Table 5 - List of various external stimuli used for formation of hydrogels and drug release from the crosslinked polymer matrix ${ }^{59}$

\begin{tabular}{|c|c|c|c|c|}
\hline $\begin{array}{l}\text { Vanjska pobuda } \\
\text { External stimuli }\end{array}$ & $\begin{array}{l}\text { Hidrogel } \\
\text { Hydrogel }\end{array}$ & $\begin{array}{l}\text { Mehanizam } \\
\text { Mechanism }\end{array}$ & $\begin{array}{l}\text { Polimeri } \\
\text { Polymers }\end{array}$ & $\begin{array}{l}\text { Referencije } \\
\text { Reference }\end{array}$ \\
\hline $\begin{array}{l}\text { temperatura } \\
\text { temperature }\end{array}$ & $\begin{array}{l}\text { temperaturno osjetljivi } \\
\text { hidrogelovi } \\
\text { thermoresponsive hydrogels }\end{array}$ & $\begin{array}{l}\text { promjena temperature - promjena u } \\
\text { bubrenju - oslobađanje lijeka } \\
\text { change in temperature - change in } \\
\text { swelling - release of the drug }\end{array}$ & $\begin{array}{l}\text { PNIPAAm; } \\
\text { PDEAAm }\end{array}$ & $60-63,58$ \\
\hline $\mathrm{pH}$ & $\begin{array}{l}\text { kiselo/bazni hidrogelovi } \\
\text { acidic/basic hydrogels }\end{array}$ & $\begin{array}{l}\text { promjena pH uzrokuje bubrenje i } \\
\text { oslobađanje lijeka } \\
\text { change in } \mathrm{pH} \text { - change in swelling - } \\
\text { release of the drug }\end{array}$ & PAA; PDEAEM & $64-66,58$ \\
\hline $\begin{array}{l}\text { ionska jakost } \\
\text { ionic strength }\end{array}$ & $\begin{array}{l}\text { ionski hidrogelovi } \\
\text { ionic hydrogels }\end{array}$ & $\begin{array}{l}\text { promjena u ionskoj jakosti - promjena } \\
\text { koncentracije iona unutar gela uzrokuje } \\
\text { bubrenje i oslobađanje lijeka } \\
\text { change in ionic strength - change in } \\
\text { concentration of ions inside gel causes } \\
\text { swelling and release of the drug }\end{array}$ & $\begin{array}{l}\text { neionski } \\
\text { PNIPAAm } \\
\text { nonionic } \\
\text { PNIPAAm }\end{array}$ & 67,68 \\
\hline $\begin{array}{l}\text { električni signal } \\
\text { electrical signal }\end{array}$ & $\begin{array}{l}\text { polielektrolitni hidrogelovi } \\
\text { polyelectrolyte hydrogels }\end{array}$ & $\begin{array}{l}\text { reverzibilno bubrenje pod utjecajem } \\
\text { električnog polja - oslobađanje lijeka } \\
\text { reversible swelling in the presence of } \\
\text { electrical field - release of the drug }\end{array}$ & PHEMA & 69,70 \\
\hline $\begin{array}{l}\text { magnetsko polje } \\
\text { magnetic field }\end{array}$ & $\begin{array}{l}\text { magnetske čestice dispergirane } \\
\text { u mikrosferama } \\
\text { magnetic particles dispersed in } \\
\text { microspheres }\end{array}$ & $\begin{array}{l}\text { primjena magnetskog polja - promjena u } \\
\text { bubrenju - oslobađanje lijeka } \\
\text { applied magnetic field - change in } \\
\text { swelling - release of the drug }\end{array}$ & $\begin{array}{c}\text { EVAC; } \\
\text { PNIPAAm }\end{array}$ & 71,72 \\
\hline
\end{tabular}




\subsubsection{Temperaturno osjetljivi polimeri}

Mnogi polimeri pokazuju promjene u topljivosti s obzirom na temperaturno područje i to se svojstvo može iskoristiti za razvoj polimernih otopina koje imaju tzv. sol-gel prijelaz (slika 14). Taj fazni prijelaz kontroliran je temperaturnom ovisnošću polimernog sustava o pojedininim fizikalnim ili kemijskim interakcijama koje omogućavaju umrežavanje polimernih lanaca i formiranja 3D-porozne strukture hidrogelova.

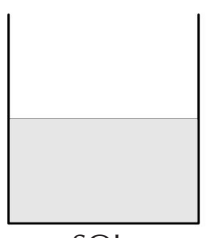

SOL

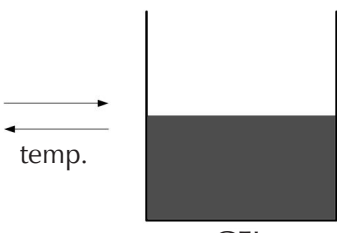

GEL

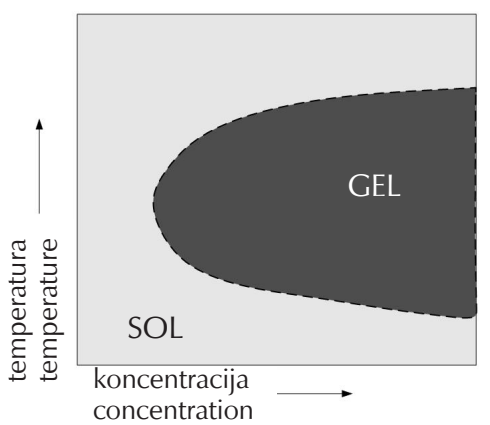

Slika 14 - Tipični fazni dijagram temperaturno-reverzibilnog prijelaza sol-gel kopolimerne otopine ${ }^{60}$

Fig. 14 - Typical phase diagram of thermoreversible sol-gel transition of copolymer solution ${ }^{60}$

Najpoznatiji polimerni sustavi kod kojih dolazi do temperaturno ovisnog sol-gel prijelaza pod utjecajem fizikalnih hidrofobnih interakcija, a primjenjuju se za razvoj naprednih terapijskih injekcijskih farmaceutskih oblika su PEO-PPOX-PEO (polietilen-oksid-block-polipropilen-oksid-block-polietilen-oksid) i PEG-PLA-PEG (polietilen-glikol-block-polilaktid-block-polietilen-glikol) kopolimeri. ${ }^{17,74,75} \mathrm{U}$ takvim sustavima za dostavu lijeka polimerna otopina lijeka injektira se na ciljano mjesto pri sobnoj temperaturi. S obzirom na to da je temperatura tijela veća od sobne (oko $37^{\circ} \mathrm{C}$ ), polimer iz otopine prelazi u čvrsto stanje prilikom čega formira polimerni matriks koji obuhvati djelatnu tvar, a produljeno oslobađanje postignuto je u početku difuzijom lijeka kroz taj matriks, a kasnije kombinacijom difuzije i degradacije biorazgradljivog polimernog matriksa. ${ }^{75}$ Primjerice, OncoGel ${ }^{\odot}$, lijek koji se sastoji od djelatne tvari paclitaxel-a i temperaturno osjetljivog polimernog sustava PLGA-PEG-PLGA $\left(\right.$ ReGel $\left.^{\odot}\right)$ služi za liječenje tumora, a dizajniran je tako da se primijeni točno u tumor, gdje će se djelatna tvar postupno oslobađati šest tjedana. ${ }^{17,75} \mathrm{~S}$ obzirom na to da se injekcija OncoGel ${ }^{\odot}$ primjenjuje izravno na mjesto gdje je tumor, na taj način izbjegnuto je njegovo dospijeće u sistemsku cirkulaciju pacijenta u većim količinama te je postignut zadovoljavajući sigurnosni profil. ${ }^{76}$ Jedan od glavnih nedostataka tako dizajniranih sustava nekontrolirani je porast koncentracije lijeka neposredno nakon primjene kao posljedica smanjenja volumena formiranog polimernog implantata prilikom čega se znatna količina djelatne tvari istisne iz polimernog matriksa (slika 15). ${ }^{75}$

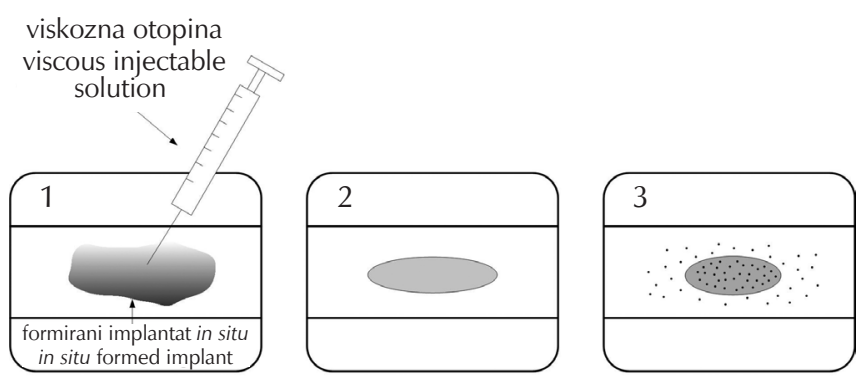

Slika 15 - Mehanizam formiranja implantata in situ na bazi hidrogela i oslobađanje lijeka iz polimernog matriksa (1 - injektiranje viskozne polimerne otopine s lijekom na ciljanom mjestu primjene; 2 - formiranje biorazgradljivog implantata in situ u kojem je dispergiran lijek; 3 - lijek se oslobađa iz polimernog matriksa difuzijom i postupnom degradacijom polimernih lanaca). ${ }^{75}$

Fig. 15 - Mechanism of in situ forming implant based on hydrogel and release of the drug from polymer matrix ( 1 - injection of viscous polymer solution with the drug at specific site of administration; 2 - in situ formation of biodegradable implant in which the drug is dispersed; 3 - drug release from the polymer matrix by diffusion and gradual erosion of polymer chains). ${ }^{75}$

\subsection{3. $\mathrm{pH}$-osjetljivi sustavi}

Fiziološki pH u tijelu čovjeka posebice u probavnom sustavu varira od primjerice $1 \mathrm{u}$ području želuca do $6-7 \mathrm{u}$ crijevima te su razvijeni razni polimerni sustavi koji reagiraju na te promjene $\mathrm{pH}$. Polimerne ovojnice oko tableta već desetljećima služe za kontrolirano oslobađanje lijeka unutar određenog područja probavnog sustava s ciljem postizanja bolje stabilnosti lijeka u kiselom području. ${ }^{1}$ Polimeri kao što su celulozni acetat-butirat i celulozni acetat-ftalat već se dulje vrijeme upotrebljavaju u tu svrhu.

Hidrogelovi na bazi polimera, koji mijenjaju svoja strukturna svojstva u različitim područjima $\mathrm{pH}$, sve se više primjenjuju i u naprednim terapijskim sustavima za kontrolirano oslobađanje lijeka. Polimeri koji sadrže ionizirajuće bočne skupine kao što su akrilna i metakrilna kiselina ${ }^{1,74}$ te dimetilamino-metakrilati mogu se primijeniti za dobivanje hidrogelova koji intenzivno bubre u vodenom mediju. Ta je transformacija potaknuta promjenom područja $\mathrm{pH}$ i vrstama bočnih skupina prisutnih u polimernim molekulama. U vodenom mediju, bočne skupine ioniziraju te do bubrenja dolazi kao posljedica djelovanja odbojnih sila između različito nabijenih bočnih skupina, pri čemu dolazi do intenzivnog upijanja vode. Negativno ili pozitivno nabijeni hidrogelovi različito će bubriti u istom području pH. Primjerice, otpuštanje kofeina iz kopolimerne matrice metil-metakrilata i N,N-dimetilaminoetil-metakrilata nije bilo značajno pri neutralnom $\mathrm{pH}$, međutim znatno se promijenilo u kiselom području. ${ }^{1}$ 
Također, razvijeni su i polimerni sustavi koji su osjetljivi na više vanjskih pobuda istodobno, kao što su primjerice $\mathrm{pH}$ i temperaturno osjetljivi PLA/PLGA-PEG diblok ili PLA/PLGA-PEG-PLA/PLGA triblok biorazgradljivi kopolimeri.

Zbog svojih brojnih prednosti sustavi za dostavu lijeka na bazi hidrogelova razvijeni su za brojne primjene i načine unosa kao što je oralna, nazalna, transdermalna, potkožna, intravenozna itd. ${ }^{59}$

lako imaju brojne prednosti, farmaceutski sustavi s kontroliranim oslobađanjem lijeka na bazi hidrogelova imaju i određena ograničenja kao što su primjerice vrlo sporo vrijeme odziva te slabija mehanička svojstva koja mogu biti ključna za pojedine primjene. Sposobnost brzog bubrenja hidrogelova u vodi može dovesti i do brzog oslobađanja lijeka i posljedično do znatno brže degradacije polimera ukoliko je glavni mehanizam degradacije hidroliza.

\section{Zaključak}

Polimeri imaju nezamjenjivu ulogu prilikom razvoja farmaceutskih proizvoda. Već dugi niz godina primjenjuju se kao pomoćne tvari za razvoj oralnih farmaceutskih oblika, gdje služe najviše kao vezivna sredstva ili sredstva za rahljenje te za izradu primarne i sekundarne ambalaže. U novije vrijeme primjena sintetičkih biorazgradljivih i biokompatibilnih polimera u farmaceutskoj industriji usmjerena je najviše na razvoj sofisticiranih farmaceutskih oblika s kontroliranim oslobađanjem djelatne tvari. Istraživanja su usmjerena prema razvoju pametnih polimernih sustava koji imaju samo regulirajuća svojstva, mogućnost isporuke lijekova kroz dulje razdoblje, dostavu lijeka na točno definirano mjesto primjene te mogućnost prepoznavanja i reagiranja na fiziološke promjene u ljudskom organizmu. Razlog njihove sve veće primjene u tom području farmaceutske industrije leži u tome što polimerne molekule posjeduju jedinstvena fizikalno-kemijska svojstva koja se ne mogu postići niti jednom drugom vrstom materijala te se mogu dizajnirati s velikom mogućnošću varijacija prilagođenih specifičnim vrstama primjene. To je rastuća znanstvena grana kako u akademskoj zajednici tako i u industriji te zahtijeva multidisciplinaran pristup, a poznavanje fundamentalnih spoznaja polimerne kemije i kemijsko-inženjerskih principa nužni su prilikom razvoja takvih kompleksnih sustava za dostavu lijeka.

\section{Popis kratica i simbola \\ List of abbreviations and symbols}

EC

EVAC

FDA

HPMC
- etil-celuloza

- ethyl cellulose

- poli(etilen-co-vinil-acetat)

- poly(ethylene-co-vinyl acetate)

- Agencija za hranu i lijekove

- Food and Drug Administration

- hidroksipropilmetil-celuloza

- hydroxypropylmethylcellulose
MC

- metil-celuloza

- methyl cellulose

PAA

- poli(akrilna kiselina)

- poly(acrylic acid)

PCL - polikaprolakton

- polycaprolactone

PDEAAm - poli $(N, N$-dietilakrilamid $)$

- poly $(N, N$-diethylacrylamide)

PDMS - poli(dimetilsiloksan)

- polydimethylsiloxane

PEG-PLA-PEG - polietilen-glikol-block-polilaktid-block-polietilen-glikol

- polyethylene glycol-block-polylactide-block-polyethylene glycol

PEO-PPOX-PEO - polietilen-oksid-block-polipropilen-oksid-block-polietilen-oksid

- polyethylene oxide-block-polypropylene oxide-block-polyethylene oxide

PGA - poliglikolid

- polyglycolide

$\mathrm{pH}$

- numerička skala koja se primjenjuje za određivanje kiselosti ili bazičnosti vodene otopine

- numeric scale used to specify the acidity or basicity of an aqueous solution

PDEAEM

- poli(dietilaminoetil-metakrilat)

- poly(diethylaminoethyl methacrylate)

PHEMA - poli(2-hidroksietil-metakrilat)

- poly(2-hydroxyethyl methacrylate)

PLA

- polilaktid

- polylactide

PLGA - poli(laktid-co-glikolid)

- poly(lactide-CO-glycolide)

PLGA-PEG-PLGA - poli(laktid-co-glikolid)-block-polietilen-glikol-block-poli(laktid-co-glikolid)

- poly(lactide-co-glycolide)-block-polyethylene glycol-block-poly(lactide-CO-glycolide)

PNIPAAm - poli( $N$-izopropilakrilamid $)$

- poly(N-isopropylacrylamide)

PVP

- poli( $N$-vinil-pirolidon)

- poly(N-vinyl pirolidone)

PVAL

- poli(vinil-alkohol)

- poly(vinyl alcohol)

$T_{\mathrm{g}}$

- temperatura staklastog prijelaza (staklište)

- glass transition temperature

\section{Literatura}

\section{References}

1. D. Jones, Pharmaceutical applications of polymers for drug delivery, Vol. 15, Smithers Rapra Technology, Akron, 2004.

2. H. Park, K. Park, Polymers in pharmaceutical products, u S. W. Shalaby, Y. Ikada, R. Langer, J. Williams (ur.), Polymers of biological and biomedical significance (ACS Symposium Series), American Chemical Society, Washington, DC, 1994.

3. S. C. Porter, C. H. Bruno, G. J. Jackson, Particle-coating methods, u H. A. Lieberman, L. Lachman, J.B. Schwartz (ur.), Pharmaceutical dosage forms, Vol. 3, Marcel Dekker Inc., 
New York, 1990, str. 92-117.

4. S. Ummadi, B. Shravani, N. G. R. Rao, M. S. Reddy, B. S. Nayak, Overview on controlled release dosage form, Int. J. Pharma Sci. 4 (2013) 258-269.

5. K. J. Gandhi, S. V. Deshmane, K. R. Biyani, Polymers in pharmaceutical drug delivery system: a review, Int. J. Pharm. Sci. Rev. Res. 14 (2012) 57-66.

6. S. Pallerla, B. Prabhakar, Review on polymers in drug delivery, Am. J. Pharm. Tech. Res. 3 (2013) 900-917.

7. R. Kaur, S. Kaur, Role of polymers in drug delivery, J. Drug Deliv. Ther. 4 (2014) 32-36.

8. D. L. Wise, Handbook of pharmaceutical controlled release technology, Marcel Dekker Inc., New York, 2000.

9. G. M. Jantzen, J. R. Robinson, Sustained- and controlled-release drug delivery systems, u G.S. Banker, C. T. Rhodes (ur.), Modern pharmaceutics, Marcel Dekker, Inc, New York, 2002, str. 501-528.

10. R. Gwozdz, Polymers for solid oral dosage forms, Drug Develop. Deliv. 2 (2012) 34-37.

11. G. Cole, J. Hogan, M. Aulton, Pharmaceutical coating technology. Taylor \& Francis, London, 1995, doi: https://doi. org/10.3109/9780203014356.

12. J. W. McGinity, Aqueous polymeric coatings for pharmaceutical dosage forms, Marcel Dekker, New York, 1989.

13. M. Z. I. Khan, Ž. Prebeg, N. Kurjaković, A pH-dependent colon targeted oral drug delivery system using methacrylic acid copolymers. I. Manipulation of drug release using Eudragit ${ }^{\circledR}$ L100-55 and Eudragit ${ }^{\circledR}$ S100 combinations, J. Control. Release 58 (1999) 215-222, doi: https://doi.org/10.1016/ S0168-3659(98)00151-5.

14. Eudragit ${ }^{\circledR}$ Applications Guidelines, $10^{\text {th }}$ Edition, 2008.

15. J. R. Robinson, V. H. L. Lee, Controlled drug delivery and fundamentals applications, $2^{\text {nd }}$ ed, Marcel Dekker Inc., New York, 1987, doi: https://doi.org/10.1201/b14193.

16. L. V. Allen, N. G. Popovich, H. C. Ansel, Ansel's Pharmaceutical dosage forms and drug delivery systems, $8^{\text {th }}$ ed, Lippincott Williams \& Wilkins, Philadelphia, 2004.

17. W.-W. Yang, E. Pierstorff, Reservoir-based polymer drug delivery systems, J. Lab. Autom. 17 (2012) 50-58, doi: https:// doi.org/10.1177/2211068211428189.

18. R. Langer, New methods of drug delivery, Science 249 (1990) 1527-1533, doi: https://doi.org/10.1126/science.2218494.

19. A. G. Ozturk, S. S Ozturk, B. O. Palsson, T. A. Wheatley, J.B. Dressman, Mechanism of release from pellets coated with an ethylcellulose-based film, J. Control. Release 14 (1990) 203 213, doi: https://doi.org/10.1016/0168-3659(90)90160-U.

20. J. L. Bourges, C. Bloquel, A. Thomas, F. Froussart, A. Bochot, F. Azan, R. Gurny, D. BenEzra, F. Behar-Cohen, Intraocular implants for extended drug delivery: therapeutic applications, Adv. Drug Deliv. Rev. 58 (2006) 1182-1202, doi: https://doi. org/10.1016/j.addr.2006.07.026.

21. G. R. da Silva, S. L. Fialho, R. C. Siqueira, R. Jorge, A. D. Cunha, Implants as drug delivery devices for the treatment of eye diseases, Braz. J. Pharm. Sci. 46 (2010) 585-595, doi: https://doi.org/10.1590/S1984-82502010000300024.

22. M. Chen, H. J. Huang, E. Pierstorff, E. Shin, E. Robinson, D. A. Ho, Parylene-encapsulated copolymeric membranes as localized and sustained drug delivery platforms, Ann. Biomed. Eng. 37 (2009) 2003-2017, doi: https://doi.org/10.1007/ s10439-009-9662-9.

23. W. R. Gombotz, D. K. Pettit, Biodegradable polymers for protein and peptide drug-delivery, Bioconjugate Chem. 6 (1995) 332-351, doi: https://doi.org/10.1021/bc00034a002.

24. M. S. Shive, J. M. Anderson, Biodegradation and biocom- patibility of PLA and PLGA microspheres, Adv. Drug Deliv. Rev. 28 (1997) 5-24, doi: https://doi.org/10.1016/S0169409X(97)00048-3.

25. R. A. Jain, The manufacturing techniques of various drug loaded biodegradable poly(lactide-CO-glycolide) (PLGA) devices, Biomaterials 21 (2001) 2475-2490, doi: https://doi. org/10.1016/S0142-9612(00)00115-0.

26. K. A. Athanasiou, G. G. Niederauer, C. M. Agrawal, Sterilization, toxicity, biocompatibility and clinical applications of polylactic acid/polyglycolic acid copolymers. Biomaterials 17 (1996) 93-102, doi: https://doi.org/10.1016/01429612(96)85754-1.

27. V. R. Sinha, K. Bansal, R. Kaushik, R. Kumria, A. Trehan,

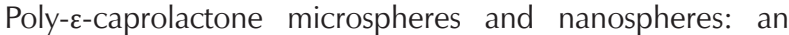
overview, Int. J. Pharm. 278 (2004) 1-23, doi: https://doi. org/10.1016/j.ijpharm.2004.01.044.

28. A. Göpferich, J. Tessmar, Polyanhydride degradation and erosion, Adv. Drug Deliv. Rev. 54 (2002) 911-931, doi: https:// doi.org/10.1016/S0169-409X(02)00051-0.

29. J. Heller, J. Barr, S. Y. Ng, K. S. Abdellauoi, R. Gurny, Poly(ortho esters): synthesis, characterization, properties and uses, Adv. Drug Deliv. Rev. 7 (2002) 1015-39, doi: https://doi. org/10.1016/S0169-409X(02)00055-8.

30. V. R. Sinha, A. Trehan, Biodegradable microspheres for protein delivery, J. Control. Release 90 (2003) 261-280, doi: https://doi.org/10.1016/S0168-3659(03)00194-9.

31. A. Lendlein, A. Sisson, Handbook of biodegradable polymers: Isolation, Synthesis, Characterization and Application, Wiley-VCH, Weinheim, Germany, 2011, doi: https://doi. org/10.1002/9783527635818.

32. A. Göpferich, Polymer degradation and erosion: mechanism and applications, Eur. J. Pharm. Biopharm. 42 (1996) 1-11.

33. F. von Burkersroda, L. Schedl, A. Göpferich, Why degradable polymers undergo surface erosion or bulk erosion, Biomaterials 23 (2002) 4221-4231, doi: https://doi.org/10.1016/ S0142-9612(02)00170-9.

34. M. Husmanna, S. Schenderleina, M. Lücka, H. Lindnera, P. Kleinebuddeb, Polymer erosion in PLGA microparticles produced by phase separation method, Int. J. Pharm. 242 (2002) 277-280, doi: https://doi.org/10.1016/S03785173(02)00187-4

35. J. Manish, K. Abhay, Sustained release matrix type drug delivery system: a review, J. Drug Deliv. Ther. 2 (2012) 142-148.

36. H. Patel, D. R. Panchal, U. Patel, T. Brahmbhatt, M. Suthar, Matrix type drug delivery system: a review, JPSBR 3 (2011) 143-151.

37. J. Grund, M. Koerber, M. Walther, R. Bodmeier, The effect of polymer properties on direct compression and drug release from water-insoluble controlled release matrix tablets, Int. J. Pharm. 469 (2014) 94-101, doi: https://doi.org/10.1016/j. ijpharm.2014.04.033.

38. P. Colombo, R. Bettini, P. Santi, N.A. Peppas, Swellable matrices for controlled drug delivery: gel-layer behaviour, mechanisms and optimal performance, Pharm. Sci. Technol. Today 3 (2000) 198-204, doi: https://doi.org/10.1016/S14615347(00)00269-8.

39. R. Cortese, F. Theeuwes (Alza Corporation), Osmotic device with hydrogel driving member, US patent 4,327,725, 4 May 1982.

40. R. L. Jerzewski, Y. W. Chien, Osmotic drug delivery, u Treatise on controlled drug delivery: fundamentals, optimization, application, Marcel Dekker, New York, 1992, str. 225-253.

41. J. L. Jensen, L. E. Appel, H. Clair, G.M. Zentner, Variables that affect the mechanism of drug release from osmotic pumps coated with acrylate methacrylate copolymer la- 
texes, J. Pharm. Sci. 84 (1995) 530-533, doi: https://doi. org/10.1002/jps.2600840503.

42. M. M. Feldstein, V. N. Tohmakhchi, L. B. Malkhazov, A. E. Vasiliev, N. A. Platé, Hydrophilic polymeric matrices for enhanced transdermal drug delivery, Int. J. Pharm. 131 (1996) 229-242, doi: https://doi.org/10.1016/03785173(95)04351-9.

43. R. H. Guy, J. Hadgraft, Transdermal drug delivery systems: $2^{\text {nd }}$ ed, revised and expanded, Marcel Dekker, New York, 2003.

44. N. A. Peppas, Y. Huang, M. Torres-Lugo, J. H. Ward, J. Zhang, Physicochemical, foundations and structural design of hydrogels in medicine and biology, Annu. Rev. Biomed. Eng. 2 (2000) 9-29, doi: https://doi.org/10.1146/annurev.bioeng.2.1.9.

45. T. R. Hoare, D. S. Kohane, Hydrogels in drug delivery: progress and challenges, Polymer 8 (2008) 1993-2007, doi: https://doi.org/10.1016/j.polymer.2008.01.027.

46. K. R. Kamath, K. Park, Biodegradable hydrogels in drug delivery, Adv. Drug Deliv. Rev. 11 (1993) 59-84, doi: https://doi. org/10.1016/0169-409X(93)90027-2.

47. J. Zhang, N. A. Peppas, Morphology of poly(methacrylic acid)/poly( $N$-isopropyl acrylamide) interpenetrating polymeric networks, J. Biomater. Sci 13 (2002) 511-525, doi: https://doi.org/10.1163/15685620260178373.

48. B. D. Ratner, A. S. Hoffman, Hydrogels for medical and related applications, ACS Publications, Washington DC, 1976.

49. N. A. Peppas, Hydrogels in medicine and pharmacy, CRC Press, Boca Raton, 1986.

50. N. A. Peppas, R. Langer, New challenges in biomaterials, Science 263 (1994) 1715-1720, doi: https://doi.org/10.1126/ science.8134835.

51. A. S. Hoffman, Hydrogels for biomedical applications, Adv. Drug Deliv. Rev. 54 (2002) 3-12, doi: https://doi. org/10.1016/S0169-409X(01)00239-3.

52. J. Jagur-Grodzinski, Polymeric gels and hydrogels for biomedical and pharmaceutical applications, Polymer. Adv. Tech. 21 (2009) 27-47, doi: https://doi.org/10.1002/pat.1504.

53. B. K. Nanjawade, F. V. Manvi, A. S. Manjappa, In situ-forming hydrogels for sustained ophthalmic drug delivery, J. Control. Release 122 (2007) 119-134, doi: https://doi.org/10.1016/j. jconrel.2007.07.009.

54. L. Xinming, C. Yingde, A. W. Lloyd, S. V. Mikhalovsky, S. R. Sandeman, C. A. Howel, L. Liewen, Polymeric hydrogels for novel contact lens-based ophthalmic drug delivery systems: a review, Cont. Lens. Anterior Eye 31 (2008) 57-64, doi: https://doi.org/10.1016/j.clae.2007.09.002.

55. S. Brahim, D. Narinesingh, A. Guiseppi-Elie, Polypyrrole-hydrogel composites for the construction of clinically important biosensors, Biosens. Bioelectron. 17 (2002) 53-59, doi: https://doi.org/10.1016/S0956-5663(01)00262-7.

56. N. B. Graham, M. E. McNeill, Hydrogels for controlled drug delivery, Biomaterials 5 (1984) 27-36, doi: https://doi. org/10.1016/0142-9612(84)90063-2.

57. C. Shih, Chain-end scission in acid catalyzed hydrolysis of poly(D,L-lactide) in solution, J. Control. Release 34 (1995) 9-15, doi: https://doi.org/10.1016/0168-3659(94)00100-9.

58. Y. Qiu, K. Park, Enviroment-sensitive hydrogels for drug delivery, Adv. Drug Deliv. Rev. 53 (2001) 321-339, doi: https:// doi.org/10.1016/S0169-409X(01)00203-4.

59. S. Simões, A. Figueiras, F.Veiga, Modular hydrogels for drug delivery, J. Biomater. Nanobiotechnol. 3 (2012) 185-199, doi: https://doi.org/10.4236/jbnb.2012.32025.

60. B. Jeong, S. W. Kim, Y. H. Bae, Thermosensitive sol-gel reversible hydrogels, Adv. Drug Deliv. Rev. 54 (2002) 37-51, doi: https://doi.org/10.1016/S0169-409X(01)00242-3.
61. E. Ruel-Gariépy, J. C. Leroux, In situ-forming hydrogels-review of temperature-sensitive systems, Eur. J. Pharm. Biopharm. 58 (2004) 409-426, doi: https://doi.org/10.1016/j. ejpb.2004.03.019.

62. X. Zhang, R. Zhuo, Synthesis of temperature-sensitive poly(N-isopropylacrylamide) hydrogel with improved surface property, J. Colloid. Interface Sci. 223 (2000) 311-313, doi: https://doi.org/10.1006/jcis.1999.6654.

63. L. Pérez-Alvarez, V. S. Martínez, E. Hernáez, I. Katime, Novel $\mathrm{pH}$ - and temperature-responsive methacrylamide microgels, Macromol. Chem. Physic. 210 (2009) 1120-1126, doi: https://doi.org/10.1002/macp.200900058.

64. J. Ma, X. Liu, Z. Yang, Z. Tong, A pH-sensitive hydrogel with hydrophobic association for controlled release of poorly water-soluble drugs, J. Macromol. Sci. Pure Appl. Chem. 46 (2009) 816-820, doi: https://doi. org/10.1080/10601320903004707.

65. L. Brannon-Peppas, N. A. Peppas, Equilibrium swelling behavior of $\mathrm{pH}$-sensitive hydrogels, Chem. Eng. Sci. 46 (1991) 715-722, doi: https://doi.org/10.1016/00092509(91)80177-Z

66. A. Richter, G. Paschew, S. Klatt, J. Lienig, K.-F. Arndt, H. J. Adler, Review on hydrogel-based $\mathrm{pH}$ sensors and microsensors, Sensors 8 (2008) 561-581, doi: https://doi.org/10.3390/ s8116999.

67. M. Karbarz, W. Hyka, Z. Stojek, Swelling ratio driven changes of probe concentration in $\mathrm{pH}$ - and ionic strength-sensitive poly(acrylic acid) hydrogels, Electrochem. Commun. 11 (2009) 1217-1220, doi: https://doi.org/10.1016/j.elecom.2009.04.005

68. H. Li, Y. K. Yew, Simulation of soft smart hydrogels responsive to $\mathrm{pH}$ stimulus: ionic strength effect and case studies, Mater. Sci. Eng. C 29 (2009) 2261-2269, doi: https://doi. org/10.1016/j.msec.2009.05.011.

69. H. Li, R. Luo, K. Y. Lam, Modeling of ionic trans- port in electric-stimulus-responsive hydrogels, J. Membrane Sci. 289 (2007) 284-296, doi: https://doi.org/10.1016/j.memsci.2006.12.011.

70. H. Li, Kinetics of smart hydrogels responding to electric field: a transient deformation analysis, Int. J. Solids Structures 46 (2009) 1326-1333, doi: https://doi.org/10.1016/j.ijsolstr.2008.11.001.

71. R. Ramanujan, K. Ang, S. Venkatraman, Magnet-PNIPA hydrogels for bioengineering applications, J. Mater. Sci. 44 (2009) 1381-1387, doi: https://doi.org/10.1007/s10853006-1064-x

72. M. Namdeo, S. K. Bajpai, S. Kakkar, Preparation of a magnetic-field-sensitive hydrogel and preliminary study of its drug release behaviour, J. Biomater. Sci. Polym. Ed. 20 (2009) 17471761, doi: https://doi.org/10.1163/156856208X386372.

73. P. Ferreira, J. F. J. Coelho, J. F. Almeida, M. H. Gil, Photocrosslinkable polymers for biomedical applications, u R. Fazel (ur.), Biomedical engineering - frontiers and challenges, INTECH, 2011.

74. K. Al-Tahami, J. Singh, Smart polymer based delivery systems for peptides and proteins, Recent Pat. Drug Deliv. Formul. 1 (2007) 65-71, doi: https://doi. org/10.2174/187221107779814113.

75. S. Kempe, K. Mäder, In situ forming implants - an attractive formulation principle for parenteral depot formulations, J. Control. Release 161 (2012) 668-679, doi: https://doi. org/10.1016/j.jconrel.2012.04.016.

76. N. L. Elstad, K. D. Fowers, OncoGel (ReGel/paclitaxel) clinical applications for a novel paclitaxel delivery system, Adv. Drug Deliv. Rev. 61 (2009) 785-794, doi: https://doi. org/10.1016/j.addr.2009.04.010. 


\section{SUMMARY \\ Application of Polymers in Pharmaceutical Industry Ivana Šoljić Jerbić}

Polymers and polymeric materials have been used in the pharmaceutical industry for many years and play an indispensable role as excipients in the development of the conventional dosage forms or for manufacturing various drug packaging materials. In recent years, their important application resides in the development of sophisticated drug delivery systems where the release of the drug over a longer time period is mainly controlled by degradation kinetics of the applied polymer. It is preferable that polymers introduced into the human body be biodegradable, meaning that they should eventually completely decompose to nontoxic products that can be naturally excreted from the body. In addition, they should be biocompatible, and in contact with the living organism, should not cause undesirable side effects, although their retention in the tissue could be for a longer time. Such designed complex drug delivery systems where polymers are used as functional excipients have numerous advantages, such as simplicity of administration and targeted drug delivery to the desired site, extended and controlled release, which reduces frequency of drug administration. This can consequently lead to reducing adverse side effects of administered drugs and improvement of patient compliance. There is a range of differently designed drug delivery systems and their description and mechanism of action will be presented in this paper together with the prominent role of the polymers for each particular system.

\section{Keywords}

Polymers, pharmaceutical dosage forms, controlled release, hydrogels

PLIVA Croatia Ltd., Research and Development

Prilaz baruna Filipovića 25

Review

10000 Zagreb, Croatia

Received September 5, 2016

Accepted January 12, 2017 